\title{
Quantification of Plasma-Produced Hydroxyl Radicals in Solution and their Dependence on the $\mathrm{pH}$
}

\author{
Francesco Tampieri, Maria-Pau Ginebra, and Cristina Canal* \\ Cite This: https://dx.doi.org/10.1021/acs.analchem.0c04906 \\ Read Online
}

ACCESS | Lill Metrics \& More | 回 Article Recommendations | S1 Supporting Information

\begin{abstract}
HO radicals are the most important reactive species generated during water treatment by non-thermal plasma devices. In this letter, we report the first quantification of the steady-state concentration and lifetime of plasma-produced hydroxyl radicals in water solutions at $\mathrm{pH} 3$ and 7 , and we discuss the differences based on their reactivity with other plasma-generated species. Finally, we show to what extent the use of chemical probes to quantify shortlived reactive species has an influence on the results and that it should be taken into account.
\end{abstract}
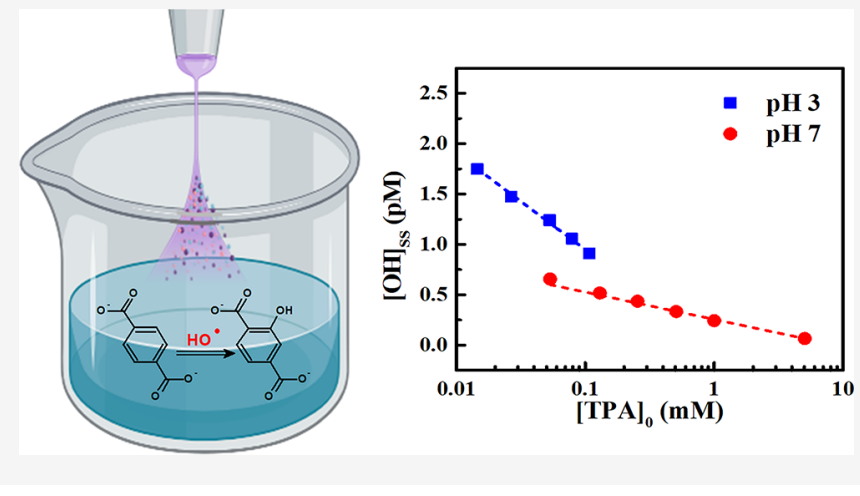

$\mathrm{T}$ he wide variety of applications that cold atmospheric plasmas (CAPs) reached in the last decades, ranging from gas conversion to agriculture and from the environment to manufacturing and medicine, ${ }^{1-5}$ is mostly due to the fine tunability of the nature and amount of reactive species (RS) that are produced by a CAP in a gas or in a liquid. This has been possible thanks to the correlation of the RS production with the CAP parameters and to the methods and protocols that have been developed and adapted to detect and quantify plasma-produced RS. ${ }^{6-8}$ The majority of them are focused on the long-lived species, like $\mathrm{O}_{3}, \mathrm{H}_{2} \mathrm{O}_{2}, \mathrm{H}_{3} \mathrm{O}^{+}, \mathrm{NO}_{2}{ }^{-}$, and $\mathrm{NO}_{3}{ }^{-}$, because their reactivity can be more easily controlled and their quantification can be done after the treatment, without interference from the plasma. ${ }^{7,9-12}$ Nevertheless, analysis of short-lived RS (especially $\mathrm{HO}^{\bullet}, \mathrm{O}_{2}^{-\bullet}, \mathrm{HOO}^{\bullet}$, and $\mathrm{OONO}^{-}$) is of paramount importance because they are primarily responsible for the biological action during direct CAP treatments and are the source of the long-lived ones. ${ }^{13}$

HO radicals are probably the most important reactive species produced by plasma treatment of water solutions. They can oxidize unselectively the majority of organic compounds they come in contact with, and by radical recombination, they are the main source of hydrogen peroxide in plasma systems. ${ }^{14}$ Due to intrinsic and experimental limitations (i.e., its high reactivity), the detection and quantification of $\mathrm{HO}$ radicals, especially in the liquid phase, is often indirect and nonquantitative; ${ }^{15}$ therefore, the amount of information that can be obtained is limited. The main methods involve the use of chemical probes that react selectively with the $\mathrm{HO}$ radicals to give relatively stable adducts/products that can be detected spectroscopically (by electron paramagnetic resonance if they have unpaired electrons or by fluorimetry if they are fluorescent). ${ }^{8}$ The methods for the quantification of RS differ whether they are short or long-lived; contrary to what occurs for long-lived species, the concentration of $\mathrm{HO}$ radicals and other short-lived RS (like superoxide, peroxonitrite, singlet oxygen, etc.) cannot be quantified by simply multiplying their formation rate by the treatment time because, due to their high reactivity, they are not stable and thus do not accumulate in solution. For this reason, only the steady-state concentration can be obtained. Previous works applying the method suitable for long-lived species to $\mathrm{HO}^{\bullet}$ obtained surprisingly high values in the micromolar range. ${ }^{16-19}$ When dealing with short-lived RS, to obtain reliable values of the steady-state concentration in solution, it is mandatory to know the fraction of all produced RS that is being captured by the probe and the sum of all the other contributions, other than the reaction with the probe, that lead to their consumption. ${ }^{20}$

In this letter, we report the first quantification of $\mathrm{HO}^{*}$ steady-state concentration and lifetime in water at different $\mathrm{pH}$ values, produced by nonthermal plasma, according to the above-mentioned method. These values are then used to discuss briefly the chemical mechanisms that lead to generation and consumption of the radicals, with a focus on the ones that are $\mathrm{pH}$-dependent. The use of a chemical probe to detect and

Received: November 20, 2020

Accepted: January 21, 2021 
quantify short-lived reactive species in solution may affect the results obtained, so this is also discussed here.

The source that we used in this work to generate the plasma is an atmospheric pressure plasma jet (APPJ) based on a single electrode that works with helium as the feed gas (more details in the Supporting Information (SI)). To detect $\mathrm{HO}$ radicals in water solution, we employed the widely used chemical probe terephthalate (TPA). ${ }^{16,17,21,22}$ In solution, $\mathrm{HO}$ radicals react with TPA giving 2-hydroxyterephtalate (hTPA) as the main product (Scheme 1). hTPA is fluorescent $\left(\lambda_{\mathrm{ex} / \mathrm{em}}=310 / 425\right.$

Scheme 1. Chemical Structures of TPA (terephthalate) and hTPA (2-hydroxyterephthalate)

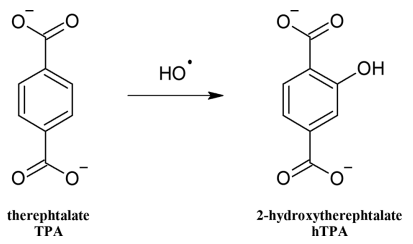

$\mathrm{nm})$. The yield of the reaction of TPA with $\mathrm{HO}$ radicals has been reported to be $35 \%$ in the presence of oxygen by ultrasound radiation chemical studies ${ }^{23}$ with a second-order reaction rate constant $(4.4 \pm 0.1) \times 10^{9} \mathrm{M}^{-1} \mathrm{~s}^{-1} .^{24}$ Other common plasma-generated $\mathrm{RS}\left(\mathrm{HO}_{2}{ }^{\bullet}, \mathrm{O}_{2}{ }^{-\bullet}, \mathrm{H}_{2} \mathrm{O}_{2}\right)$ were reported not to interfere with $\mathrm{HO}^{\bullet}$ in reactions with TPA. ${ }^{25}$
Some recent publications reported the hydroxylation of phenol and terephthalate by CAP-generated atomic oxygen. $^{26-28}$ However, according to these works, when pure helium is used as plasma feed gas, the amount of atomic oxygen produced is at least 1 order of magnitude lower than $\mathrm{HO}$ radicals and is expected to rapidly decay by increasing the plasma-target distance. Moreover, optical emission spectroscopy (OES) experiments on our source under the conditions reported in this work (Figure S1, Supporting Information) confirm the presence of an atomic oxygen signal only in the region close to the plasma nozzle. For these reasons, we may assume that the contribution of the $\mathrm{O}$ atoms to TPA hydroxylation is minor and can be neglected under our experimental conditions.

We treated with plasma TPA solutions with different initial concentrations, in phosphate buffer (PB) at $\mathrm{pH} 3$ and 7, for selected times. Due to the $\mathrm{pH}$-dependence of the TPA solubility in water, the range of initial concentrations that we were able to explore at $\mathrm{pH} 3$ and 7 were different $(15-100 \mu \mathrm{M}$ at $\mathrm{pH} 3$ and $50-5000 \mu \mathrm{M}$ at $\mathrm{pH} 7)$. We determined the concentrations of residual TPA and of plasma-generated hTPA in solution by HPLC/UV analysis of the treated solutions (Figure $1 \mathrm{a}$ and $\mathrm{b}$ for $\mathrm{pH} 3$ and Figure S4, Supporting Information, for $\mathrm{pH} 7$ ). As discussed in the SI, fluorescence measurements were not used here because there are additional fluorescent products of the reaction that lead to an overestimation of the concentration, thus a chromatographic separation step is required. We then calculated the rates of
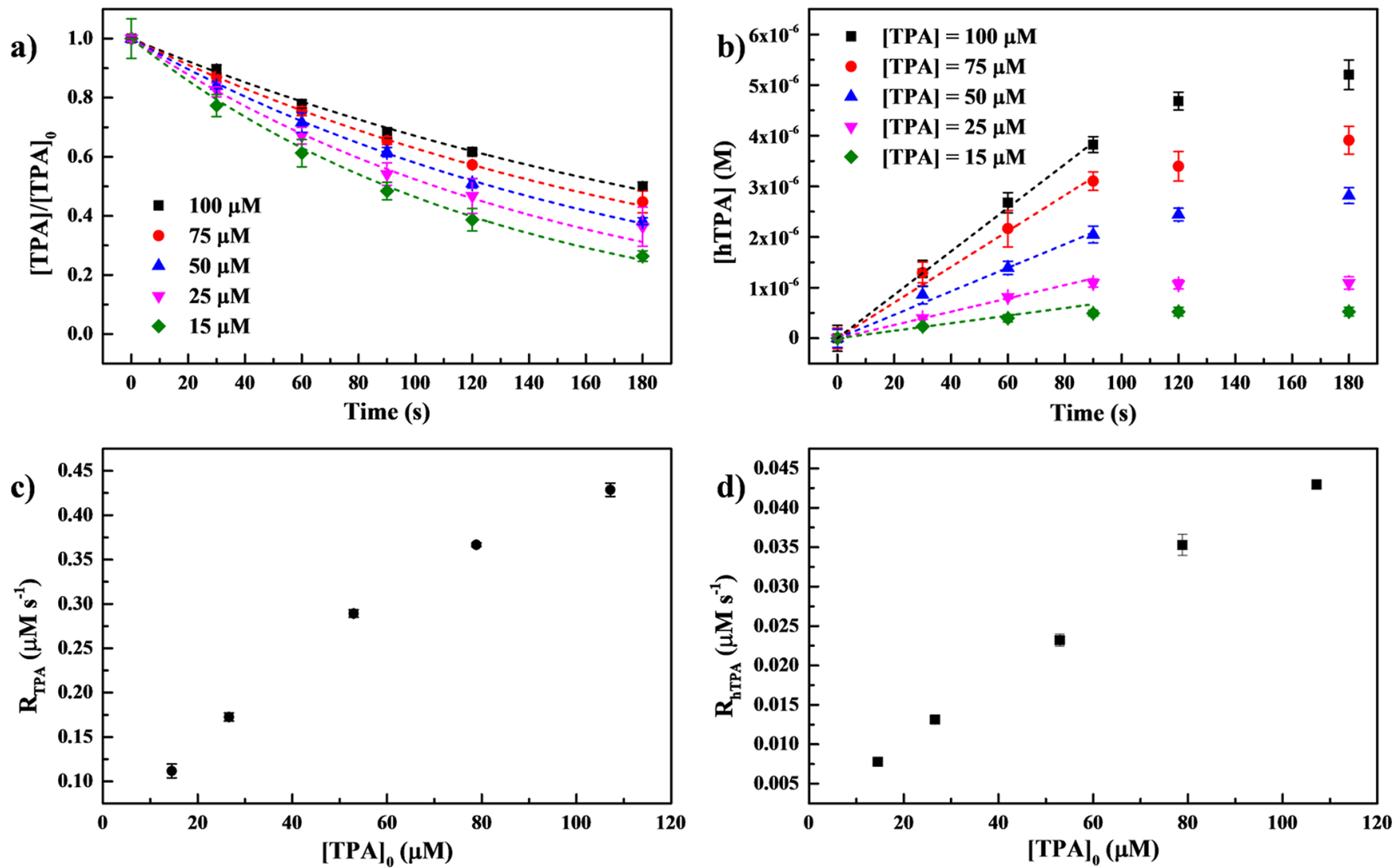

Figure 1. (a) TPA residual concentration (normalized) as a function of the treatment time for different initial nominal concentrations in $\mathrm{PB} 100$ $\mathrm{mM}, \mathrm{pH}$ 3. (b) Concentration of hTPA as a function of treatment time for different TPA initial nominal concentrations in PB $100 \mathrm{mM}, \mathrm{pH} 3$. (c) Rate of decrease of TPA concentration as a function of TPA real initial concentration at pH 3. (d) Rate of increase of hTPA concentration as a function of TPA real initial concentration at $\mathrm{pH} 3$. 
decrease of TPA concentration $\left(R_{\text {TPA }}\right)$ and the rates of increase of hTPA concentration $\left(R_{\mathrm{hTPA}}\right)$ for all the initial TPA concentrations (Figure 1c and $\mathrm{d}$ for $\mathrm{pH} 3$ and Figure S5, Supporting Information, for $\mathrm{pH} 7$ ) by fitting of the points in Figure $1 \mathrm{a}$ and $\mathrm{b}$ using exponential and linear functions, respectively. For longer treatment times, linearity in Figure $1 \mathrm{~b}$ is lost because hTPA is oxidized by CAP-generated RS. For this reason, to calculate $R_{\mathrm{hTPA}}$, we used only the experimental points obtained for the short treatment times (lower than $90 \mathrm{~s}$ ) when the degradation of hTPA is negligible. ${ }^{29}$

We used these rates to calculate the yield of hTPA formation ( $\left.Y_{\mathrm{hTPA}}=R_{\mathrm{hTPA}} / R_{\mathrm{TPA}}\right)$ in all the conditions studied, and we found that it increases with the TPA initial concentration and apparently does not depend significantly on the $\mathrm{pH}$ of the solution in the range of 3-7 studied in this work (Figure $2 \mathrm{a}$ ).
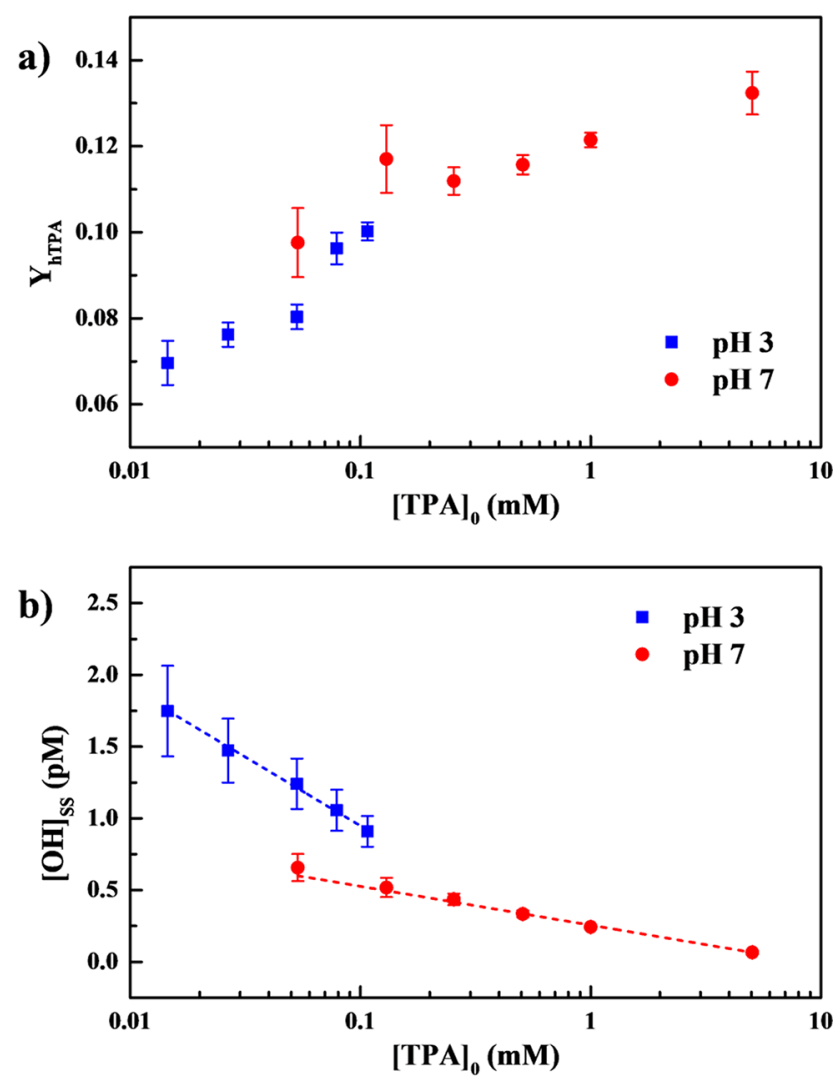

Figure 2. (a) Yield of hTPA formation as a function of TPA initial concentration at $\mathrm{pH} 3$ and 7. (b) Steady-state concentration of $\mathrm{OH}$ radicals as a function of TPA initial concentration at $\mathrm{pH} 3$ and 7.

The yields that we obtained are lower than the one reported in the literature; ${ }^{23,30}$ the difference can be explained considering the different concentration used and, especially, the presence of reactive species other than $\mathrm{HO}^{\bullet}$ in the CAPtreated liquid. These other species compete with $\mathrm{HO}^{\bullet}$ for the reaction with the TPA.

Next, we determined the rate of formation of HO radicals, their lifetime, and their steady-state concentration in solution (Table 1) following the procedure reported by Anifowose et al., $^{20}$ as detailed in the SI. The same procedure has been used recently by Cabrellon et al. to quantify plasma-generated superoxide. $^{29}$ The $\mathrm{HO}^{\bullet}$ steady-state concentration is also reported in Figure $2 b$ as a function of TPA initial concentration. According to our measurements, the formation
Table 1. Lifetime $\left(t_{1 / 2}\right)$, Rate of formation $\left(R_{\mathrm{HO}}\right)$, and Steady-State Concentration ${ }^{a}\left([\mathrm{HO}]_{\mathrm{SS}}\right)$ of Plasma-Generated HO Radicals in Solution at $\mathrm{pH} 3$ and 7

\begin{tabular}{lcc}
\multicolumn{1}{c}{ Parameter } & $\mathrm{pH} 3$ & $\mathrm{pH} 7$ \\
$t_{1 / 2}(\mathrm{~ns})$ & $550 \pm 50$ & $201 \pm 15$ \\
$R_{\mathrm{HO}}\left(\mathrm{nmol} \mathrm{s}^{-1}\right)$ & $1.9 \pm 0.3$ & $2.1 \pm 0.4$ \\
{$[\mathrm{HO}]_{\mathrm{sS}}(\mathrm{pM})$} & $1.8 \pm 0.3$ & $0.70 \pm 0.13$
\end{tabular}

${ }^{a}$ The values of $[\mathrm{HO}]_{\mathrm{SS}}$ are extrapolated at zero TPA concentration.

rate of $\mathrm{HO}$ radicals is the same, within the experimental error, at $\mathrm{pH} 3$ and $7\left(2 \mathrm{nmol} \mathrm{s}{ }^{-1}\right)$, while its lifetime is almost three times higher at acidic $\mathrm{pH}$ (550 ns at $\mathrm{pH} 3$ and $201 \mathrm{~ns}$ at $\mathrm{pH} 7$ ). This determines a higher steady-state concentration at $\mathrm{pH} 3$ (1.8 $\mathrm{pM}$ vs 0.70 at $\mathrm{pH} 7$ ).

Considering the formation rate, our plasma source is quite efficient in the production of $\mathrm{HO}$ radicals, if compared with other sources designed for water treatment reported in the literature. ${ }^{10,12,14,16,17,21}$ To the best of our knowledge, this is the first reasonable quantification of steady-state concentration of plasma-produced $\mathrm{HO}$ radicals, so a comparison of this parameter with previous work based on plasma technology is not possible. However, our results fit well in the range of $\mathrm{HO}$ radicals steady-state concentrations based on other advanced oxidation processes, $10^{-12}$ to $10^{-17} \mathrm{M}^{24,31-34}$

By analyzing the values reported in Table 1 , we notice that in our system the main processes responsible for $\mathrm{HO}^{\bullet}$ generation do not depend on $\mathrm{pH}$ (in the range of 3-7), while those that lead to $\mathrm{HO}^{\bullet}$ consumption are more efficient at $\mathrm{pH}$ 7. Gorbanev et al. reported that the main contributions to $\mathrm{HO}^{\bullet}$ generation in a helium plasma jet in contact with water happen in the plasma effluent, and then, the radicals can diffuse into the liquid. ${ }^{35}$ Thus, the generation rate of the radicals is expected not to depend strongly on the $\mathrm{pH}$ of the solution, as we indeed found. There are also other contributions to $\mathrm{HO}^{\bullet}$ generation that come from reactions of other plasma-generated reactive species in solution (Table S3, Supporting Information). Some of them can be affected by the $\mathrm{pH}$, but they account for a small fraction of the total.

In order to explain the differences found at $\mathrm{pH} 3$ and 7 in the $\mathrm{HO}^{\bullet}$ consumption efficiency, we reviewed the acid-base equilibria of the main species produced by plasma in liquids (Table S2, Supporting Information) and checked the possible reactions that can consume $\mathrm{HO}$ radicals during plasma treatment of a water solution in the presence of ambient air (Table 2). The acid-base equilibria of superoxide, nitrous acid, and peroxynitrous acid have $\mathrm{p} K_{\mathrm{a}}$ in our $\mathrm{pH}$ range of interest $(4.8,3.4$, and 6.5 respectively, see SI). Thus, we expect to have the species $\mathrm{HO}_{2}{ }^{\circ}, \mathrm{HOONO}$, and co-presence of $\mathrm{HNO}_{2} / \mathrm{NO}_{2}{ }^{-}$at $\mathrm{pH} 3$ and $\mathrm{O}_{2}{ }^{-\bullet}, \mathrm{NO}_{2}{ }^{-}$, and co-presence of $\mathrm{HOONO} / \mathrm{OONO}^{-}$at $\mathrm{pH}$ 7. If we focus on the reactions of $\mathrm{HO}^{\bullet}$ with superoxide (Table 2 , eqs 2 and 3 ) and with nitrite ions (Table 2, eqs 9 and 10), we notice that both are faster when the superoxide and nitrite are deprotonated, thus explaining the lower lifetime of $\mathrm{HO}$ radicals at $\mathrm{pH} 7$ than at $\mathrm{pH}$ 3. Peroxynitrous acid is formed mainly under acidic conditions, ${ }^{11}$ so it is expected not to play a major role at $\mathrm{pH} 7$.

The HO steady-state concentration in solution is defined as the ratio between its formation rate and the sum of the rates of all the contributions that consume it (see eq S4, Supporting Information). The presence of most organic molecules (including TPA and the other typical probes that are used to detect $\mathrm{HO}$ radicals) in solution increases the number of 
Table 2. Reactions of Hydroxyl Radicals with Other Reactive Species in Solution ${ }^{a}$

\begin{tabular}{cccc}
\multicolumn{3}{c}{ Reactions of $\mathrm{HO}^{\bullet}$ radicals } & $k\left(\mathrm{M}^{-1} \mathrm{~s}^{-1}\right)$ \\
\hline 1 & $\mathrm{HO}^{\bullet}+\mathrm{e}^{-} \rightarrow \mathrm{HO}^{-}$ & $3.0 \times 10^{10}$ \\
2 & $\mathrm{HO}^{\bullet}+\mathrm{HO}^{\bullet} \rightarrow \mathrm{H}_{2} \mathrm{O}_{2}$ & & $4.0 \times 10^{9}$ \\
3 & $\mathrm{HO}^{\bullet}+\mathrm{HO}_{2}^{\bullet} \rightarrow \mathrm{O}_{2}+\mathrm{H}_{2} \mathrm{O}$ & & $7.0 \times 10^{9}$ \\
4 & $\mathrm{HO}^{\bullet}+\mathrm{O}_{2}^{-\bullet} \rightarrow \mathrm{O}_{2}+\mathrm{HO}^{-}$ & & $1.0 \times 10^{10}$ \\
5 & $\mathrm{HO}^{\bullet}+\mathrm{H}_{2} \mathrm{O}_{2} \rightarrow \mathrm{H}_{2} \mathrm{O}+\mathrm{HO}_{2}^{\bullet}$ & & $2.7 \times 10^{7}$ \\
6 & $\mathrm{HO}^{\bullet}+\mathrm{O}_{3} \rightarrow \mathrm{O}_{2}+\mathrm{HO}_{2}^{\bullet}$ & & $2 \times 10^{9}$ \\
7 & $\mathrm{HO}^{\bullet}+\mathrm{NO}^{\bullet} \rightarrow \mathrm{HNO}_{2}$ & $2 \times 10^{10}$ \\
8 & $\mathrm{HO}^{\bullet}+\mathrm{NO}_{2}^{\bullet} \rightarrow \mathrm{HOONO}^{\circ}$ & $1.3 \times 10^{9}$ \\
9 & $\mathrm{HO}^{\bullet}+\mathrm{HNO}_{2} \rightarrow \mathrm{NO}_{2}^{\bullet}+\mathrm{H}_{2} \mathrm{O}$ & $1 \times 10^{9}$ \\
10 & $\mathrm{HO}^{\bullet}+\mathrm{NO}_{2}^{-} \rightarrow \mathrm{NO}_{2}^{\bullet}+\mathrm{HO}^{-}$ & $1.0 \times 10^{10}$
\end{tabular}

${ }^{a}$ Adapted with permission from ref 36 . Copyright 2012, John Wiley and Sons.

possible pathways that lead to consumption of $\mathrm{HO}$ radicals, the effect being more important if the amount of organic matter in solution is higher. This is evident from Figure $2 b$, where the steady-state concentration of $\mathrm{HO}$ radicals decreases with increasing TPA initial concentration. This behavior is not limited to the present study, but it is typical in all cases where the determination of a highly reactive species is done by using a chemical probe, the presence of the probe itself influencing the results of the measurement. Here, to get a correct value for the $\mathrm{HO}$ radical steady-state concentration, we extrapolated our experimental data at zero TPA concentration.

To summarize, here we presented the first quantification of $\mathrm{HO}^{\bullet}$ lifetime and steady-state concentration produced by plasma in solution obtained by first calculating the fraction of $\mathrm{HO}^{\bullet}$ that is being captured by TPA and the sum of all the other contributions that lead to their consumption. This allowed us to observe a $\mathrm{pH}$ dependence of the generation and reactivity of $\mathrm{HO}$ radicals that can help understand the trends obtained for other related/derived species (e.g., hydrogen peroxide).

\section{ASSOCIATED CONTENT}

\section{sI Supporting Information}

The Supporting Information is available free of charge at https://pubs.acs.org/doi/10.1021/acs.analchem.0c04906.

Experimental section, optical emission spectroscopy experiments; comparison between fluorescence and HPLC/UV-vis; treatment of TPA solutions with different initial concentrations at $\mathrm{pH} \mathrm{7}$; calculation of the rate of formation of $\mathrm{HO}$ radicals; their lifetime; and their steady-state concentration at $\mathrm{pH} 3$ and 7; acidbase equilibria of the main species produced by plasma in liquids; and reactions of plasma-generated RS in solution contributing to $\mathrm{HO}^{\bullet}$ generation (PDF)

\section{AUTHOR INFORMATION}

\section{Corresponding Author}

Cristina Canal - Biomaterials, Biomechanics and Tissue Engineering Group, Department of Materials Science and Metallurgy, Technical University of Catalonia (UPC), 08019 Barcelona, Spain; Barcelona Research Center in Multiscale Science and Engineering, Universitat Politècnica de
Catalunya, Barcelona, Spain; Research Centre for Biomedical Engineering, Universitat Politècnica de Catalunya, Barcelona, Spain; 이이이.org/0000-0002-3039-7462;

Email: cristina.canal@upc.edu

\section{Authors}

Francesco Tampieri - Biomaterials, Biomechanics and Tissue Engineering Group, Department of Materials Science and Metallurgy, Technical University of Catalonia (UPC), 08019 Barcelona, Spain; Barcelona Research Center in Multiscale Science and Engineering, Universitat Politècnica de Catalunya, Barcelona, Spain; Research Centre for Biomedical Engineering, Universitat Politècnica de Catalunya, Barcelona, Spain; orcid.org/0000-0003-1474-867X

Maria-Pau Ginebra - Biomaterials, Biomechanics and Tissue Engineering Group, Department of Materials Science and Metallurgy, Technical University of Catalonia (UPC), 08019 Barcelona, Spain; Barcelona Research Center in Multiscale Science and Engineering, Universitat Politècnica de Catalunya, Barcelona, Spain; Research Centre for Biomedical Engineering, Universitat Politècnica de Catalunya, Barcelona, Spain; Institute for Bioengineering of Catalonia, Barcelona Institute of Science and Technology, Barcelona, Spain; (1) orcid.org/0000-0002-4700-5621

Complete contact information is available at:

https://pubs.acs.org/10.1021/acs.analchem.0c04906

\section{Notes}

The authors declare no competing financial interest.

\section{ACKNOWLEDGMENTS}

This project was funded by the ERC (N.714793). Authors acknowledge PID2019-103892RB-I00 and belong to SGR2017 1165. M.P.G. thanks Generalitat de Catalunya for ICREA Academia Award.

\section{REFERENCES}

(1) Weltmann, K.-D.; Kolb, J. F.; Holub, M.; Uhrlandt, D.; Simek, M.; Ostrikov, K.; Hamaguchi, S.; Cvelbar, U.; Cernak, M.; Locke, B.; Fridman, A.; Favia, P.; Becker, K.; et al. Plasma Processes Polym. 2019, 16 (1), 1800118.

(2) Bekeschus, S.; Favia, P.; Robert, E.; von Woedtke, T. Plasma Processes Polym. 2019, 16 (1), 1800033.

(3) Cvelbar, U.; Walsh, J. L.; Černák, M.; de Vries, H. W.; Reuter, S.; Belmonte, T.; Corbella, C.; Miron, C.; Hojnik, N.; Jurov, A.; et al. Plasma Processes Polym. 2019, 16 (1), 1700228.

(4) Brandenburg, R.; Bogaerts, A.; Bongers, W.; Fridman, A.; Fridman, G.; Locke, B. R.; Miller, V.; Reuter, S.; Schiorlin, M.; Verreycken, T.; et al. Plasma Processes Polym. 2019, 16 (1), 1700238.

(5) Simek, M.; Černák, M.; Kylián, O.; Foest, R.; Hegemann, D.; Martini, R. Plasma Processes Polym. 2019, 16 (1), 1700250.

(6) Bruggeman, P J; Kushner, M J; Locke, B R; Gardeniers, J G E; Graham, W G; Graves, D B; Hofman-Caris, R C H M; Maric, D; Reid, J P; Ceriani, E; Fernandez Rivas, D; Foster, J E; Garrick, S C; Gorbanev, Y; Hamaguchi, S; Iza, F; Jablonowski, H; Klimova, E; Kolb, J; Krcma, F; Lukes, P; Machala, Z; Marinov, I; Mariotti, D; Mededovic Thagard, S; Minakata, D; Neyts, E C; Pawlat, J; Petrovic, Z L.; Pflieger, R; Reuter, S; Schram, D C; Schroter, S; Shiraiwa, M; Tarabova, B; Tsai, P A; Verlet, J R R; von Woedtke, T; Wilson, K R; Yasui, K; Zvereva, G; et al. Plasma Sources Sci. Technol. 2016, 25 (5), 053002.

(7) Khlyustova, A.; Labay, C.; Machala, Z.; Ginebra, M.-P.; Canal, C. Front. Chem. Sci. Eng. 2019, 13 (2), 238-252.

(8) Gorbanev, Y.; Bogaerts, A. Chemical Detection of Short-Lived Species Induced in Aqueous Media by Atmospheric Pressure Plasma. 
In Atmospheric Pressure Plasma - from Diagnostics to Applications; IntechOpen, 2019.

(9) Labay, C.; Hamouda, I.; Tampieri, F.; Ginebra, M.-P.; Canal, C. Sci. Rep. 2019, 9, 16160.

(10) Nani, L.; Tampieri, F.; Ceriani, E.; Marotta, E.; Paradisi, C. J. Phys. D: Appl. Phys. 2018, 51 (27), 274002.

(11) Bosi, F. J.; Tampieri, F.; Marotta, E.; Bertani, R.; Pavarin, D.; Paradisi, C. Plasma Processes Polym. 2018, 15 (3), 1700130.

(12) Tampieri, F.; Giardina, A.; Bosi, F. J.; Pavanello, A.; Marotta, E.; Zaniol, B.; Neretti, G.; Paradisi, C. Plasma Processes Polym. 2018, 15 (6), 1700207.

(13) Fridman, A.; Friedman, G. Plasma Medicine; Wiley, 2013.

(14) Joshi, A. A.; Locke, B. R.; Arce, P.; Finney, W. C. J. Hazard. Mater. 1995, 41 (1), 3-30.

(15) Gorbanev, Y.; Privat-Maldonado, A.; Bogaerts, A. Anal. Chem. 2018, 90 (22), 13151-13158.

(16) Sahni, M.; Locke, B. R. Ind. Eng. Chem. Res. 2006, 45 (17), 5819-5825.

(17) Kanazawa, S.; Furuki, T.; Nakaji, T.; Akamine, S.; Ichiki, R. J. Phys.: Conf. Ser. 2013, 418, 012102.

(18) Tresp, H.; Hammer, M. U.; Weltmann, K.-D.; Reuter, S. Plasma Med. 2013, 3 (1-2), 45-55.

(19) Jose, J.; Ramanujam, S.; Philip, L. Chem. Eng. J. 2019, 360, 1341-1354.

(20) Anifowose, A. J.; Takeda, K.; Sakugawa, H. Anal. Chem. 2015, 87 (24), 11998-12005.

(21) Kanazawa, S.; Kawano, H.; Watanabe, S.; Furuki, T.; Akamine, S.; Ichiki, R.; Ohkubo, T.; Kocik, M.; Mizeraczyk, J. Plasma Sources Sci. Technol. 2011, 20 (3), 034010.

(22) Gonzalez, D. H.; Kuang, X. M.; Scott, J. A.; Rocha, G. O.; Paulson, S. E. Anal. Lett. 2018, 51 (15), 2488-2497.

(23) Fang, X.; Mark, G.; von Sonntag, C. Ultrason. Sonochem. 1996, $3(1), 57-63$.

(24) Page, S. E.; Arnold, W. A.; McNeill, K. J. Environ. Monit. 2010, $12(9), 1658$.

(25) Kanazawa, S.; Furuki, T.; Nakaji, T.; Akamine, S.; Ichiki, R. Int. J. Plasma Environ. Sci. Technol. 2012, 6 (2), 166-171.

(26) Hefny, M. M.; Pattyn, C.; Lukes, P.; Benedikt, J. J. Phys. D: Appl. Phys. 2016, 49 (40), 404002.

(27) Benedikt, J.; Mokhtar Hefny, M.; Shaw, A.; Buckley, B. R.; Iza, F.; Schäkermann, S.; Bandow, J. E. Phys. Chem. Chem. Phys. 2018, 20 (17), 12037-12042.

(28) Myers, B.; Ranieri, P. J.; Smirnova, T.; Hewitt, P.; Peterson, D.; Herrera Quesada, M.; Lenker, E.; Stapelmann, K. J. Phys. D: Appl. Phys. 2021, na DOI: 10.1088/1361-6463/abd9a6.

(29) Cabrellon, G.; Tampieri, F.; Rossa, A.; Barbon, A.; Marotta, E.; Paradisi, C. ACS Sensors 2020, 5 (9), 2866-2875.

(30) Mark, G.; Tauber, A.; Laupert, R.; Schuchmann, H.-P.; Schulz, D.; Mues, A.; von Sonntag, C. Ultrason. Sonochem. 1998, 5 (2), 4152.

(31) Huang, N.; Wang, W.-L.; Xu, Z.-B.; Lee, M.-Y.; Wu, Q.-Y.; Hu, H.-Y. Chem. Eng. J. 2020, 382, 122856.

(32) Manfrin, A.; Nizkorodov, S. A.; Malecha, K. T.; Getzinger, G. J.; McNeill, K.; Borduas-Dedekind, N. Environ. Sci. Technol. 2019, 53 (15), 8553-8562.

(33) Dong, W.; Li, L.; Chen, X.; Yao, Y.; Ru, Y.; Sun, Y.; Hua, W.; Zhuang, G.; Zhao, D.; Yan, S. Appl. Catal., B 2019, 246, 284-295.

(34) Hora, P. I.; Novak, P. J.; Arnold, W. A. Environ. Sci. Water Res. Technol. 2019, 5 (5), 897-909.

(35) Gorbanev, Y.; O’Connell, D.; Chechik, V. Chem. - Eur. J. 2016, 22 (10), 3496-3505.

(36) Pandis, S. N.; Seinfeld, J. H. J. Geophys. Res. 1989, 94 (D1), $1105-1126$. 